\title{
Gambaran Kepedulian Pendidik di TPQ Nurul Yaqin Jorong Kp.Tujuh, Nagari Tj. Betung, Rao Selatan, Kab. Pasaman Rahmiati Fitia Marta ${ }^{{ }^{*}}$ Wisroni $^{1}$
}

\author{
${ }^{1}$ Jurusan Pendidikan Luar Sekolah, Fakultas Ilmu Pendidikan Universitas Negeri Padang \\ *e-mail: rahmiatifitriamarta96@gmail.com
}

(Diterima: 20 April 2020, direvisi: 15 Mei 2020, disetujui: 30 Mei 2020)

\begin{abstract}
Abstrak
Penelitian ini dilatar belakangi oleh tingginya prestasi murid TPQ Nurul Yaqin di Jorong Kp. Tujuh, Nagari Tj. Betung, Kec. Rao Selatan Kab. Pasaman. Penelitian ini bertujuan untuk menggambarkan kepedulian pendidik yang dilihat dari aspek pemahaman, kesadaran,dan perhatian dan empati pendidik. Jenis penelitian ini adalah penelitian deskriptif kuantitatif. Populasi dalam penelitian ini adalah seluruh murid TPQ Nurul Yaqin yang berjumlah 30 orang. Sampel diambil sebanyak $75 \%$ yakni sebanyak 23 orang, dengan teknik stratified random sampling. Teknik pengumpulan data menggunakan wawancara, dan alat pengumpulan data berupa pedoman wawancara. Teknik analisis data menggunakan rumus persentase. Hasil penelitian menunjukkan bahwa: 1) Pemahaman pendidik terhadap murid di TPQ Nurul Yaqin sudah dikatakan cukup tinggi; 2) Kesadaran pendidi terhadap murid di TPQ Nurul Yaqin cukup tinggi; dan 3) Perhatian dan empati pendidik terhadap murid di TPQ Nurul Yaqin sudah dikatan cukup tinggi.
\end{abstract}

Kata Kunci: kepedulian, pendidik MTQ, Penelitian deskriptif kuantitatif.

\begin{abstract}
This research is motivated by the high achievement of TPQ students Nurul Yaqin in Kp. Tujuh Village Tj. Betung, South Rao District. Pasaman. This study purpose to describe the concerns of educators viewed from aspects of understanding, awareness, and attention and empathy of educators. This type of research is quantitative descriptive research. The population in this study were all TPQ students Nurul Yaqin, amounting to 30 people. Samples were taken as much as 75\% namely as many as 23 people, with stratified random sampling technique. Data collection techniques using interviews, and data collection tools in the form of interview guidelines. Data analysis techniques using the percentage formula. The results showed that: 1) The understanding of educators towards students in TPQ Nurul Yaqin was already said to be quite high; 2) Education awareness of students in TPQ Nurul Yaqin is quite high; and 3) The attention and empathy of educators towards students in TPQ Nurul Yaqin has been quite high.
\end{abstract}

Keywords: caring, MTQ educators, quantitative descriptive research. 


\section{PENDAHULUAN}

Pendidikan adalah aktivitas terpenting yang harus dilakukan pada kehidupan kita, semua individu berhak mendapatkan pendidikan guna pencapaian tingkat kehidupan yang semakin hari semakin maju. Maka dari itu pendidikan sangat diperlukan bagi seluruh manusia untuk bisa melanjutkan kehidupan selanjutnya. UU No. 20 tahun 2003 mengenai pendidikan nasional menyebutkan bahwasanya pendidika itu ialah sebagai bentuk aktivitas yang dilakukan dengan terencana dan secara sadar yang mempunyai tujuan untuk menciptakan lingkungan pembelajaran yang menjadikan peserta didik dapat secara aktif meningkatkan potensinya agar mempunyai kecerdasan, kepribadian, pengendalian diri, kekuatan agama yang diperlukan[8].

Di dalam [2] disebutkan "sistem pendidikan nasional meliputi sistem pendidikan sekolah dan luar sekolah yang mana kedua sistem ini saling menopang dan saling melengkapi. Sub sistem pendidikan luar sekolah meliputi program pendidikan informal dan nonformal, dilaksanakan dalam pengalaman keluarga sehari-hari dan dilakukan dalam masyarakat melalui pelatihan, kelompok belajar, kursus dan lain-lain”. Di Indonesia, untuk memperoleh pendidikan bisa dilakukan melalui tiga jalur yaitu jalur pendidikan formal, nonformal dan informal.

Satuan pendidikan nonformal dinyatakan dalam UU No. 20 tahun 2003 tentang Sisdiknas pasal 26 ayat 4 meliputi lembaga pelatihan, kursus, majelis taklim, pusat kegiatan belajar masyarakat serta pendidikan sejenis yang meliputi sanggar seni, didikan subuh, wirid remaja, Majelis ta'lim, Taman Qiraa'atul Quran (TQA), Taman Pendidikan Al-Quran (TPQ), dan pondok pesantren [8].

Dilihat dari penjelasan tersebut maka Taman Pendidikan Al-Quran (TPQ tergolong jenis pendidikan nonformal yang dapat diselenggarakan oleh masyarakat atau lembaga dengan tujuan yaitu agara dapat memberikan pengajaran agama Islam seperti pengajaran membaca Al-Quran, dan pemahaman dasar-dasar dinul islam yang dimulai dari anak usia dini hingga orang dewasa. Kurikulum di TPQ menekankan kepada penanaman dasar-dasar dalam membaca Al-Quran serta juga berupaya dalam membantu perkembangan kerohanian anak didik supaya mempunyai kesiapan untuk melanjutkan pendidikannya.

Taman Pendidikan Quran Nurul Yaqin merupakan bentuk lembaga pendidikan nonformal jenis keagamaan yang berdiri pada Tahun 1997 yang beralamat di Jorong Kampung Tujuh Nagari Tanjung Betung Kecamatan Rao Selatan Kabupaten Pasaman. Berdasarkan wawancara dengan salah satu guru TPQ Nurul Yaqin yaitu Bapak Mardan, diketahui bahwa jumlah murid pada tahun 2019 di TPQ tersebut berjumlah 30 orang dan dibagi ke dalam dua kelas belajar yaitu kelas belajar Al-Quran dan kelas belajar iqro'.

Diketahui bahwa TPQ yang ada di Jorong Kp.Tujuh terdapat dua TPQ yaituTPQ Nurul Yaqin dan TPQ Mu'minin. Dari segi murid TPQ Nurul Yaqin memiliki lebih banyak murid dan selalu bertambah setiap tahunnya dibandingkan dengan TPQ Mu'minin. Jumlah murid TPQ Nurul Yaqin pada tahun 2019 berjumlah 30 orang sedangkan TPQ Mu'minin berjumlah 21 orang.

Tidak saja dari segi jumlah muridnya saja TPQ Nurul Yaqin sudah banyak meraih prestasi dari tahun ketahun dibandingkan dengan TPQ Mu'minin, dibuktikan dengan 
TPQ tersebut selalu mengutus muridnya dalam Musabaqoh Tilawatil Quran (MTQ) mulai dari tingakat Nagari, Kecamatan, Kabupaten bahkan sudah ada murid dari TPQ tersebut yang sudah beberapa kali meraih juara tingkat Provinsi.

Tabel 1. Prestasi Murid TPQ Nurul Yaqin dari Tahun 2014-2019

\begin{tabular}{ccccccc}
\hline \multirow{2}{*}{ No } & Tahun & Jumlah & \multicolumn{4}{c}{ Prestasi di tingkat } \\
\cline { 3 - 6 } & & & Nagari & Kecamatan & Kabupaten & Provinsi \\
\hline 1 & 2014 & 5 orang & - & 2 orang & 2 orang & 1 orang \\
2 & 2015 & 3 orang & - & - & 3 orang & - \\
3 & 2016 & 3 orang & - & - & 3 orang & - \\
4 & 2017 & 8 orang & 3 orang & 2 orang & 2 orang & 1 orang \\
5 & 2018 & 7 orang & 3 orang & 2 orang & 2 orang & - \\
6 & 2019 & 8 orang & 4 orang & 3 orang & 3 orang & 1 orang \\
\hline
\end{tabular}

Dilihat dari jumlah murid TPQ Nurul Yaqin yang mendapat juara dari 5 tahun terakhir ini TPQ Nurul Yaqin sudah bisa dikatakan berhasil dibandingkan dengan TPQ Mu'minin.

Keberhasilan TPQ Nurul Yaqin diduga disebabkan oleh adanya kepedulian pendidik terhadap TPQ tersebut, kemauan belajar anak didik yang cukup tinggi, dorongan dari orang tua, pengalaman mengajar pendidik, dandukungan dari perangkat desa/jorong yang cukup baik terhadap keberadaan TPQ Nurul Yaqin tersebut.

Slameto [7] mengatakan ada dua faktor yang memengaruhi keberhasilan belajar yaitu faktor intern dan ekstern. Faktor intern meliputi: 1) faktor jasmani seperti, faktor kesehatan, dan cacat tubuh; 2) faktor psikologi; dan 3) faktor kelelahan. Sedangkan faktor ekstern yaitu: 1) faktor keluarga seperti hubungan antar anggota keluarga, keadaan ekonomi dan lain sebagainya; dan 2) faktor sekolah seperti metode mengajar, hubungan murid dengan guru, metode belajar dan lain sebagainya.

Salah satu penyebab keberhasilan TPQ Nurul Yaqin adalah adanya kepedulian pendidik terhadap muridnya. Kepedulian pendidik dapat berupa sikap pemahaman, kesadaran, perhatian dan empati.

\section{Pemahaman}

Pemahaman juga salah satu sikap yang dapat memengaruhi keberhasilan belajar seorang murid, dengan adanya saling memahami antara pendidik dan murid maka akan terjalin hubungan yang baik antara pendidik dan murid sehingga memengaruhi perilaku belajar anak. Apa bila perilaku belajar anak sudah baik maka akan berpengaruh terhadap keberhasilan belajar anak.

\section{Kesadaran}

Kesadaran secara harfiah dikatakan sebagai mawas diri. Kesadaran dimaknai sebagai bentuk situasi yang menjadikan seseorang dapat mengendalikan secara penuh rangsangan yang diterimanya, baik dari eksternal maupun internal.

Atkinson dalam [9] menyebutkan bahwa kesadaran mencakup tiga hah yaitu: 1) persepsi; 2) pikiran; dan 3) perasaan

Apabila seorang pendidik memiliki tingkat kesadaran yang tinggi terhadap muridnya, maka hal itu pun akan berpengaruh terhadap hasil belajar seorang murid. Apabila seorang pendidik memiliki pola perilaku yang baik terhadap muridnya maka murid tersebut akan memberikan perilaku baik pula sehingga terjalin hubungan yang 
baik antara pendidik dan murid, maka murid tersebut akan bersemangat dalam belajar sehingga hasil belajarpun akan lebih baik pula.

\section{Perhatian dan empati}

Salah faktor yang memengaruhi keberhasilan belajar adalah perhatian. Perhatian pendidik adalah bentuk pemusatan pendidik terhadap murid dalam proses belajar untuk memenuhi kebutuhan belajarnya agar keberhasilan belajar murid yang optimal. Salah satu elemen penting bagi murid untuk meningkatkan prestasi belajarnya[7].

Dengan adanya perhatian dari seorang pendidik maka terjalin hubungan yang baik antara pendidik dan murid, dengan adanya hubungan yang baik antara keduanya maka anak tersebut akan termotivasi dalam pencapaian prestasi belajar anak yang lebih baik dan lebih optimal. Dengan adanya motivasi tersebut anak akan lebih terdorong untuk mengikuti pelajaran dengan rajin sehingga hasil belajarpun akan lebih baik pula.

Empati menurut Feshbach dalam Muhrima, (2010) ialah sebuah siatusi yang dialami oleh individu ketika ia merasakan apa yang orang lain rasakan seperti halnya ia mengalami sendiri permasalahan seseorang tersebut. Perasaan yang diamalinya itu berhubungan dengan apa yang dirasakan oleh orang tersebut.

Empati juga juga termasuk faktor yang memengaruhi keberhasilan belajar, karena sikap empati dari seorang pendidik dapat memotivasi murid dalam mengikuti pembelajaran, apabila murid sudah termotivasi maka murid akan sungguh-sungguh dan lebih bersemangat dalam belajar hingga hasil yang didapatkan menjadi lebih baik pula. Sikap empati seorang pendidik dapat ditunjukan dengan cara tidak memaksakan proses pembelajaran jika anak didik mulai bosan dan dapat diselingi dengan hiburan ataupun istirahat sebentar saja.

Salah satu penyebab keberhasilan TPQ Nurul Yaqin adalah adanya kepedulian pendidik terhadap muridnya. Hubungan guru dengan murid juga salah satu memengaruhi keberhasilan dalam belajar. Guru dapat memberikan perhatian, kepedulian, dan motivasi kepada muridnya agar proses pembelajaran berjalan dengan baik sehingga hasil belajarpun menjadi lebih baik.

Didasarkan pada uraian yang sudah dikemukakan, maka tujuan penelitian ini ialah untuk: (1) mengambarkan pemahaman pendidik terhadap murid di Taman Pendidikan Quran Nurul Yaqin Nagari Tj. Betung Kec. Rao Selatan Kab. Pasaman; (2) menggambarkan kesadaran pendidik terhadap murid di Taman Pendidikan Quran Nurul Yaqin Nagari Tj. Betung Kec. Rao Selatan Kab. Pasaman; dan (3) menggambarkan perhatian dan empati pendidik terhadap murid di Taman Pendidikan Quran Nurul Yaqin Nagari Tj. Betung Kec. Rao Selatan Kab. Pasaman.

\section{METODA}

Sehubungan dengan tujuan penelitian, maka penelitian ini tergolong penelitian kuantitatif bersifat deskriptif. Penelitian deskriptif menurut Yusuf [10] ialah bentuk penelitian yang mempunyai tujuan yaitu untuk mendeskripsikan secara akurat, faktual dan sistematis mengenai sifatdan fakta-fakta populasi tertentu. Penelitian ini akan mengambarkan bagaimana kepedulian pendidik di TPQ Nurul Yaqin Jorong Kp. Tujuh, Nagari Tj. Betung, Kec. Rao Selatan, Kab. Pasaman. Populasi penelitian ini berjumlah 30 orang yang terbagi ke dalam dua kelas yaitu kelas Iqro' dan kelas belajar Al-Quran, dengan sampel diambil sebanyak $75 \%$ dari keseluruhan populasi yaitu berjumlah 23 
orang dengan mengunakan teknik stratified random sampling. Teknik pengumpulan data berupa wawancara, dan alat pengumpul data adalah pedoman wawancara. Sedangkan teknik analisa data yang digunakan yaitu dengan perhitungan persentase..

\section{HASIL DAN PEMBAHASAN}

\section{Hasil}

Berdasarkan tujuan penelitian yang telah dijelaskan bahwasanya tujuan penelitian ini ialah untuk mengambarkan bagaimana dukungan emosional pendidik di TPQ Nurul Yaqin Jorong Kp. Tujuh, Nagari Tj. Betung, Kec. Rao Selatan, Kab. Pasaman.

Gambaran Kepedulian Pendidik dilihat dari Pemahaman Pendidik Terhadap Murid di TPQ Nurul Yaqin

Pemahaman guru/ pendidik terhadap murid di TPQ Nurul Yaqin sebanyak 36,4\% responden mememilih alternatif jawaban sangat setuju (SS), sebanyak 31,0\% responden memilih alternatif jawabanm setuju (S), Sedangkan responden yang memberikan alternatif jawaban kurang setuju (KS) dan tidak setuju (TS) yaitu 17,7\% dan 10,3\% terhadap gambaran pemahaman pendidik terhadap murid di TPQ Nurul Yaqin.

Maka melalui data di atas tergambar bahwa kepedulian pendidik terhadap murid TPQ dilihat dari pemahamannya terhadap murid dikategorikan tinggi. Jika digambarkan dengan hasil histogram maka bisa diamati melalui gambar 1.

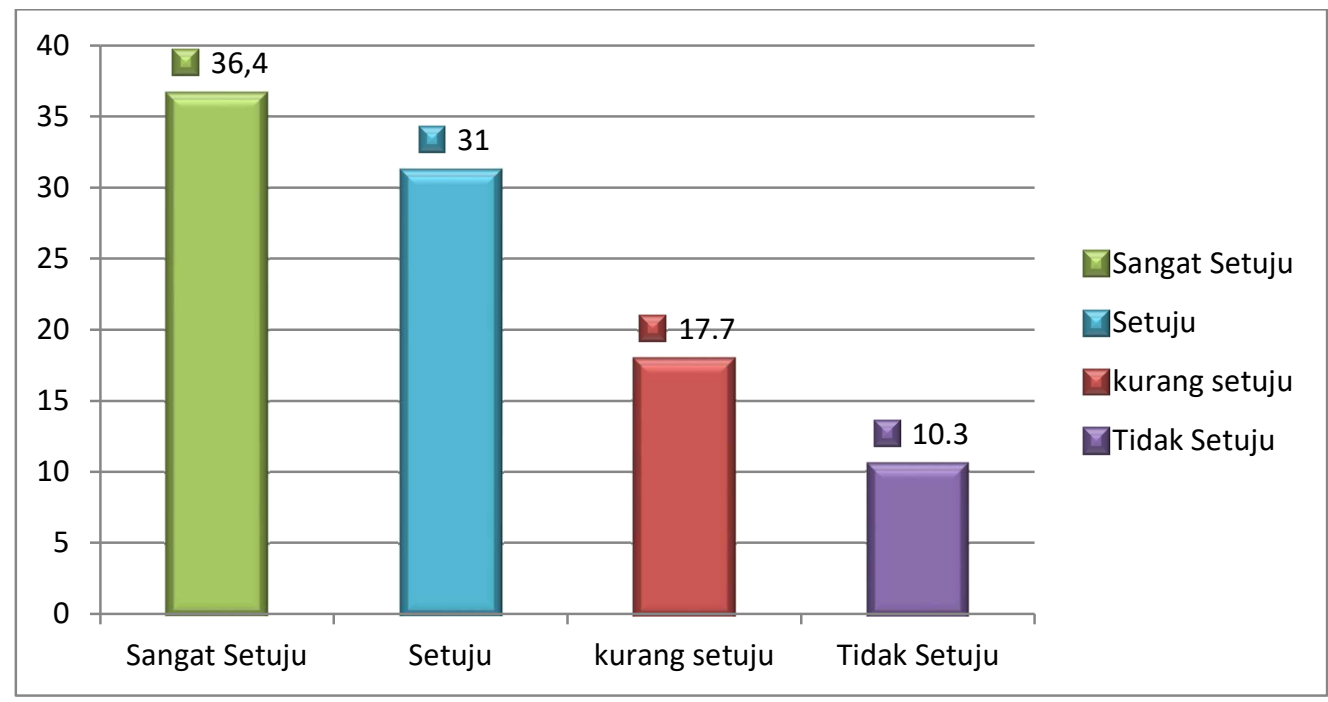

Gambar 1. Histogram Distribusi frekuensi Gambaran Kepedulian Pendidik dilihat dari Pemahaman Pendidik di TPQ Nurul Yaqin Jorong Kampung Tujuh.

Didasarkan pada hasil histogram tersebut maka bisa disimpulkan bahwasanya kepedulian pendidik dilihat dari pemahaman pendidik terhadap murid di TPQ Nurul Yaqin Jorong Kampung Tujuh sudah dikategorikan sangat tinggi, karena sebagian besar responden yang memilih alternatif jawaban sangat setuju yaitu 36,4\%. Berdasarkan gambar di atas dapat dilihat bahwa pendidik sudah memahami sebagian besar murid TPQ Nurul Yaqin dengan baik. 
Gambaran Kepedulian Pendidik di Lihat Dari Kesadaran Pendidik Terhadap Murid di TPQ Nurul Yaqin Jorog Kp Tujuh

Kesadaran pendidik terhadap murid di TPQ Nurul yaqin sebanyak 40,7\% responden memilih alternatif jawaban sangat setuju (SS), 30,9\% respenden memilih alternatif jawaban setuju (S) sedangkan responden menyatakan alternatif jawaban kurang setuju (KS) dan tidak setuju (TS) adalah 16,8\% dan 11,4\%, terhadap kesadaran pendidik terahadap murid di TPQ Nurul Yaqin.

Melalui data di atas tergambar bahwa kesadara pendidik terhadap murid di TPQ Nurul Yaqin dikategorikan sangat tinggi. Jika digambarkan dengan histogram maka terlihat pada gambar 2 .

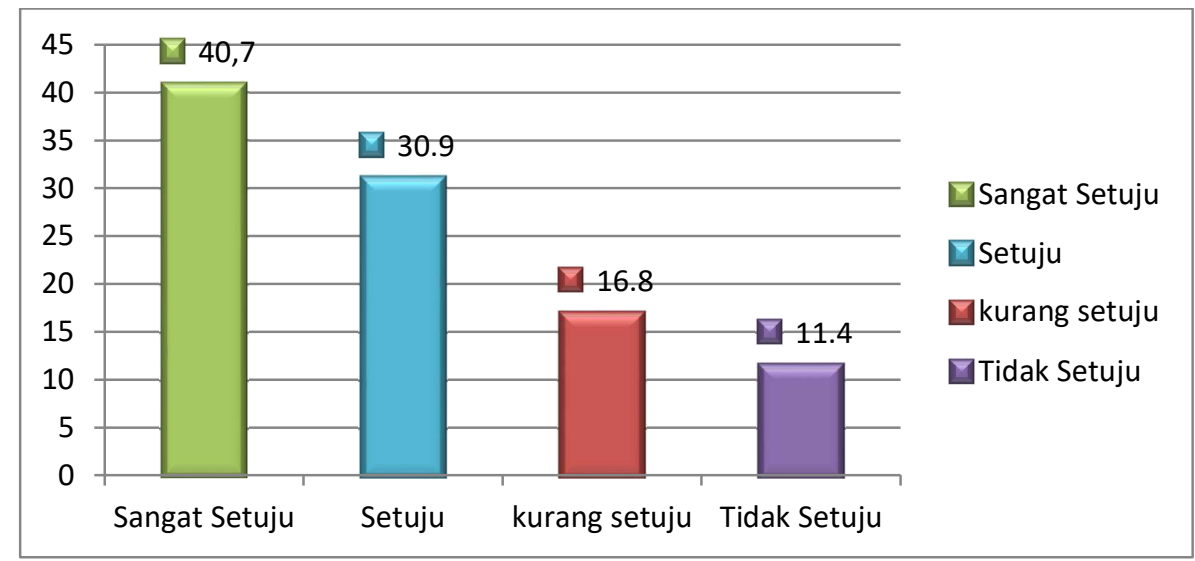

Gambar 2. Histogram Kepedulian Pendidik dilihat dari Kesadaran Pendidik Terhadap Murid di TPQ Nurul Yaqin Jrg. Kampung Tujuh.

Dari gambar 2 menunjukan bahwa kepedulian pendididk dilihat dari kesadaran pendidik terhadap murid di TPQ Nurul Yaqin dikategorikan sangat tinggi apabila diamati dari banyaknya responden yang menyatakan alternatif jawaban sangat setuju (ST) yaitu 40,7\%, sehingg dapat disimpulkan bahwa kesadaran pendidik terhadap murid sangat tinggi.

Gambaran Kepedulian Pendidik dilihat dari Perhatian dan Empati Pendidik Terhadap Murid di TPQ Nurul Yaqin

Perhatian dan empati pendidik terhadap murid di TPQ Nurul Yaqin sebanyak $42,3 \%$ responden memilih alternati jawaban sangat setuju (SS), responden memilih alternatif jawaban setuju (S) 32,0\%, sedangkan responden memilih alternatifj awaban kurang setuju (KS) dan tidak setuju (TS) adalah 16,7\%, dan 7,9\% terhadap gambaran perhatian dan empati pendidik terhadap murid di TPQ Nurul Yaqin.

Dari data di atas tergambar bahwa gambaran perhatian dan empati pendidik terhadap murid di TPQ Nurul Yaqin dikategorikan sangat tinggi. Jika digambarkan dengan histogram maka terlihat pada gambar 3.

Dari gambar 3 bisa didapatkan disimpulkan bahwasanya perhatian dan empati pendidik terhadap murid di TPQ Nurul Yaqin dikategorikan tinggi dibuktikan dari jumlah persentase responen yang memilih akternatif jawaban sangat setuju (SS) yaitu $42,3 \%$. Hal ini dapat disimpulkan bahwa kepedulian pendidik dilihat dari perhatian dan empatinya terhadap murid sangat tinggi. 


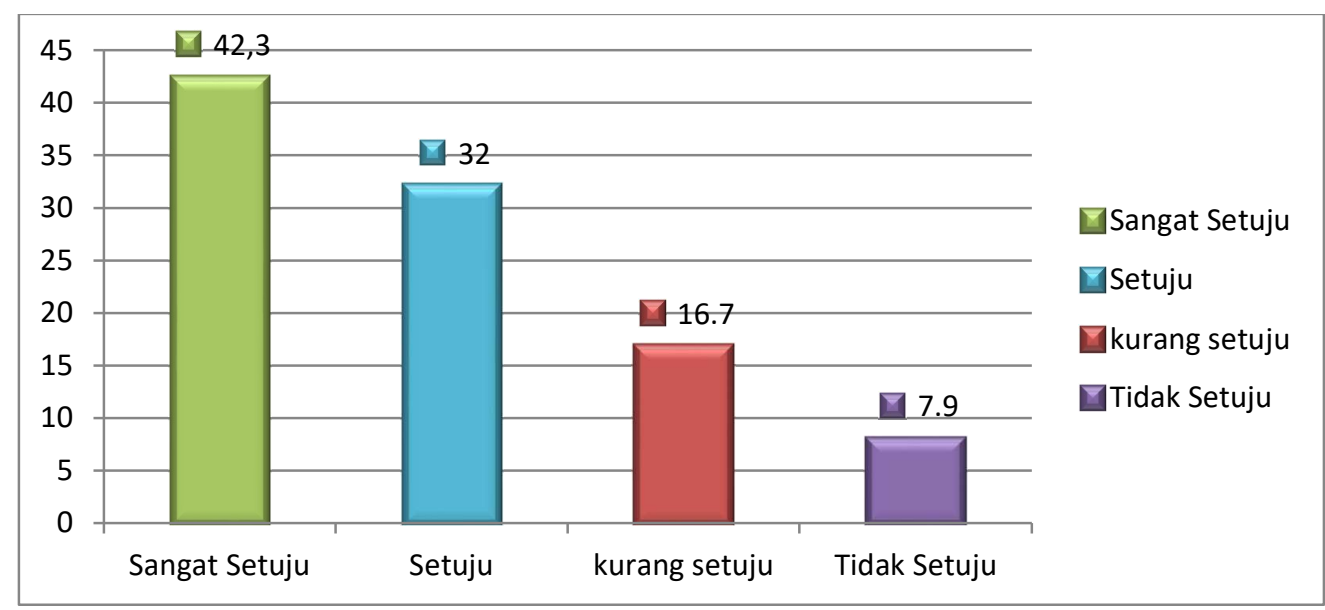

Gambar 3. Histogram Gambaran Kepedulian Pendidik dilihat dari Perhatiandan Empati Pendidik Terhadap Murid di TPQ Nurul Yaqin Jorong Kampung Tujuh.

\section{Pembahasan}

Pada bagian ini akan dijelaskan mengenai Kepedulian Pendidik di Taman Pendidikan Al-quran Jorong Kampung Tujuh Nagari Tanjung Betung Kec.Rao Selatan Kab. Pasaman seperti yang telah digambarkan pada uraian sebelumnya. Berikut penjelasannya:

Gambaran Kepedulian Pendidik dilihat dari Pemahaman Pendidik Terhadap Murid di TPQ Nurul Yaqin

Berdasarkan hasil temuan penelitian yang peneliti dapatkan menunjukkan bahwa gambaran tentang kepedulian pendidik dilihat dari pemahaman pendidik terhadap murid di TPQ Nurul Yaqin sangat tinggi, hal tersebut terbukti dengan persentase jawaban sangat setuju (SS) tergolong tinggi. Berdasarkan temuan di atas dapat dijelaskan bahwa kepedulian pendidik yang dilihat dari pemahaman pendidik terhadap murid berpengaruh terhadap proses belajar dan hasil belajar. Dengan adanya pemahaman pendidik terhadap murid akan mempermudah dalam proses belajar.

Pemahaman juga salah satu sikap yang dapat memengaruhi keberhasilan belajar seorang murid, dengan adanya saling memahami antara pendidik dan murid maka akan terjalin hubungan yang baik antara pendidik dan murid sehingga memengaruhi perilaku belajar anak. Apa bila perilaku belajar anak sudah baik maka akan berpengaruh terhadap keberhasilan belajar anak.

Menurut Rusman dalam [2] pemahaman terhadap peserta didik ialah salah satu bentuk kompetensi pedagogik yang perlu dikuasai seorang pendidik dalam pelaksaan kegiatan pembelajaran.

Pendidik harus mampu mengoptimalkan potensi murid untuk mengaktualisasikan kemampuannya dalam proses belajar, dan pendidik juga harus mampu melakukan kegiatan penilaian pembelajaran yang telah dilakukan, sehingga dapat dinyatakan dalam bentuk kemampuan guru secara pedagogik salah satunya adalah Penguasaan terhadap karakteristik peserta didik.

Dalam rangka memahami karakter anak didik secara baik, maka terdapat beberapa strategi yang bisa digunakan pendidik, yaitu: 
a. Mengenali peserta didik lebih dalam.

Tujuan dari proses pengenalan bukanlah hanya sekedar untuk mengetahui anak didik saja. Yang dikatakan mengenali adalah proses memahami anak didik secara lebih mendalam yang dilakukan secara bijaksana dan juga memerlukan proses yang panjang. Supya pendidik dapat mengenali anak didik secara lebih baik, maka cara yang bisa dilakukan pendidik ialah dengan mengunakan pendekatan psikologis, menanyakan berbagai hal yang menyangkut persoalan pribadi anak sehingga pendidik dapat menemukan cara, metode dan solusi yang harus dilakukannya.

b. Memperlakukan peserta didik secara wajar dan adil.

Dalam pengertian ini yang dikatakan adil bukanlah memberlakukan secara sama rata, melainkan memberlakukan anak didik secara bijak, memberikan bantuan kepada anak didik dengan penuh kasih sayang dan senang hati, tanpa adanya membedakan anak didik berdasarkan latar belakang apapun anak didik berasal baik itu latar belakang sosial, jenis kelamin dan sebagainya.

c. Memasuki dunia peserta didik

Supaya pendidik dapat memahami minat dan bakat anak didik secara baik, maka alangkah baiknya pendidik menjadikan dirinya bagian dari anak didik, beraktivitas secara bersama, bermain bersama sehingga dengan itu akkan menjadikan anak didik tidak akan merasa malu dan sungkan untuk berbagi pengalaman dan permasalahan yang dihadapinya.

Menjadi sahabat murid yang baik merupakan langkah guru untuk memahami setiap karakter muridnya agar lebih mudal dalam memmahami kekurangan dan kelebihannya. Menjadi sahabat murid tentu tidak hanya dengan selalu mendengarkan keluh kesah setiap murid tersebut, akan tetapi juga mendorong pribadi mereka menjadi pribadi yang mandiri.

Jadi dapat disimpulkan bahwa pemahaman adalah salah satu sikap yang harus dimiliki oleh seorang pendidik dalam belajar agar proses pembelajaran berjalan dengan lancar. Sejalan dengan penjelasan di atas hasil temuan peneliti mengenai kepedulian pendidik dilihat dari pemahaman pendidik terhadap murid di TPQ Nurul Yaqin Jrg. Kp. Tujuh Nag Tj. Betung Kec Rao Selatan Kab. Pasaman sudah dikategorikan baik, hal ini terlihat dari persentase pernyataan sangat setuju (SS) tergolong sangat tinggi.

Gambaran Kepedulian Pendidik dilihat dari Kesadaran Pendidik Terhadap Murid di TPQ Nurul Yaqin

Berdasarkan hasil temuan penelitian peneliti menujukkan bahwa gambaran kepedulian pendidik dilihat dari kesadaran pendidik terhadap murid di TPQ Nurul Yaqin tergolong bagus. Hal ini dibuktikan dengan persentase pernyataan sangat setuju (SS) menunjukkan angka tertinggi. Berdasarkan temuan di atas dijelaskan bahwa kesadaran pendidik terhadap murid dapat memengaruhi proses belajar dan berdampak kepada hasil belajar seseorang.

Kesadaran secara harfiah dikatakan sebagai mawas diri. Kesadaran dimaknai sebagai bentuk situasi yang menjadikan seseorang dapat mengendalikan secara penuh rangsangan yang diterimanya, baik dari eksternal maupun internal.

Atkinson dalam Wardani, (2008) menyebutkan bahwa kesadaran mencakup tiga hah yaitu: 


\section{a. Persepsi}

Merupakan proses pemaknaan terhadap suatu stimulus. [1] Persepsi sosial ialah suatu bentuk upaya yang dilakukan dalam rangka memahami diri kita sendiri dan orang lain. Aspek yang akan dipersepsi berkaitan dengan aspek fisik, spikologis, aspek sosial-kultural, dan aspek spiritual.

Aspek fisik merupakan aspek yang berupa bagian tubuh dari seseorang yang bisa di persepsi. Aspek psikologis bisa berupa kejiwaan seseorang, keadaan emosional dan keadaan fikiran. Aspek sosial bisa berupa tingkatan ekonomi, suku, bahasa, strata sosial dan lainnya, dan aspek psipritual adalah kepercayaan yang dianut oleh seseorang bisa berupa agama.

b. Pikiran

Pikiran merupakan ide dan proses mental. Maksud dari kata pikiran ialah bagaimana hasil dari upaya memikirkan atau potensi dalam menangkap pemikiran orang lain. Pikiran sama dengan akal atau daya pikir (untuk memahami sesuatu).

Berfikir adalah sebuah aktivitas mental hal ini dikarenakan bahwa berfikir bukan hanya mengunakan aktivitas itak melainkan juga berhubungan dengan seluruh komponen tubuh serta emosi atau perasaan secara psikologi.

c. Perasaan

Perasaan ialah kondisi yang dialami oleh seseorang sebagai akibat dari persepsi perbuatan yang memengaruhinya [3]. Jenis-jenis perasaan adalah senang, sedih, cinta, takut, malu, benci, marah, cemburu, dan lain sebagainya.

Jadi dapat disimpulkan bahwa kesadaran adalah suatu sikap yang dilakukan tanpa ada paksaa dari siapapun dalam melakukan sesuatu. Dengan adanya kesadaran dapat mempermudah murid dalam belajar. Sejalan dengan penjelasan di atas, hasil temuan peneliti mengenai gambaran kepedulian pendidik dilihat dari kesadaran pendidik terhadap murid di TPQ Nurul Yaqin dikategorikan cukup tinggi.

Gambaran Kepedulian Pendidik dilihat dari Perhatian dan Empati Pendidik Terhadap Murid di TPQ Nurul Yaqin

Berdasarkan hasil temuan penelitian peneliti menujukkan bahwa gambaran kepedulian pendidik dilihat dari perhatian dan empati pendidik terhadap murid di TPQ Nurul Yaqin tergolong bagus. Hal ini dibuktikan dengan persentase pernyataan sangat setuju (SS) menunjukkan angka tertinggi. Berdasrkan temuan di atas dapat dijelaskan bahwa perhatian dan empati dari pendidik merupakan salah satu yang dapat memberikan motivasi dalam belajar sehingga dapat memberikan hasil yang lebih baik pula.

Perhatian sebagai bentuk aktivitas yang dikerjakan seseorang dalam kaitannya mengenai pemilihan stimulus yang muncul dari lingkungan sekitarnya.[7] Stimulus yang muncul dari lingkungan bisa berbentuk keadaan dan perbuatan yang memerlukan konsentrasi yang akan terpecahkan sesudah dilakukannya pengamatan. Perhatian dapat diberikan dengan cara:

1. Pemberian bimbingan dan nasehat

Bimbingan ialah suatu langkah yang digunakan untuk membantu seseorang dalam mengatasi suatu masalah sehingga masalah tersebut dapat diselesaikan. Contoh 
bimbingan dalam belajar adalah memberikan informasi tentang cara belajar yang baik,cara memusatkan perhatian dalam belajar.

Sedangkan nasehat adalah suatu gagasan individu yang disampaikan kepada orang lain dan dianjurkan untuk melaksanakannya karenakan bisa menyelesaikan permasalahan yang dihadapinya [4].

2. Pengawasan terhadap belajar

Pengawasan terhadap belajar merupakan suatu kegiatan seorang guru untuk mengontrol atau mengoreksi suatu kegiatan pembelajaran dengan tujuan agar kegiatan tersebut berjalan dengan lancar dan tidak mengalami keselahan.

Pengawasan dalam belajar dapat berupa memberikan teguran kepada murid, bersikap tegas dan disiplin kepada anak, memberikan motivasi pada anak dengan memberikan contoh yang baik, dan memberikan arahan kepada anak dalam belajar.

3. Pemberian pengahargaan dan hukuman

Penghargaan ialah suatu bentuk apresiasi kepada seseorang atas prestasi tertentu baik berupa ucapan maupun material dengan tujuan untuk memotivasi diri agar mencapai prestasi. Penghargaan dapat diberikan dalam bentuk sertifikat, gelar, piala, medali dan lain-lain.

Sedangkan hukuman ialah suatu bentuk cara yang dilakukan guna untuk membentuk tingkah laku supaya sejalan dengan tingkah laku yang berlaku secara umum dan dapat mendidik murid agar berperilaku labih baik.

4. Pemenuhan kebutuhan belajar

Kebutuhan belajar merupakan suatu kesenjangan keadaan saat ini dibandingkan dengan keadaan seharusnya. Kebutuhan belajar setiap orang itu berbeda, kebutuhan tersebut dapat menjadi pendorong bagi seorang individu dalam belajar.

Pemenuhan kebetuhan belajar disesuaikan dengan kedaan setiap muridnya. Contoh kebutuhan belajar murid kelas Iqro' berbeda dengan kebutuhan belajar kelas Al-quran.

5. Menciptakan suasana belajar yang tenang dan tentram

Suasana kelas yang kondusif, nyaman dan tentram merupakan suatu faktor yang mempegaruhi fokus belajar anak didik, kelas yang kondusif meliputi beberapa hal seperti, ruang belajar yang nyaman, fasilitas yang memadai, kemampuan guru dalam mengelola kelas.

Empati menurut Feshbach dalam [5] ialah sebuah siatusi yang dialami oleh individu ketika ia merasakan apa yang orang lain rasakan seperti halnya ia mengalami sendiri permasalahan seseorang tersebut. Perasaan yang diamalinya itu berhubungan dengan apa yang dirasakan oleh orang tersebut.

Ada dua tahap empati. Tahap pertama ialah "pengahayatan perasaan masuk ke dalam". Seseorang akan mengalami sebuah perasaan sama dengan orang lain, misalnya keadaan marah, sakit hati. Tahap kedua, mengarah kepada sebuah kesadaran secara kognitif, mengamati dunia orang lain seperti halnya ia mengamatinya, kemudian ditujukan kepada pandangan yang lebih realistis.

Ciri-ciri dari orang yang mempunyai empati tinggi menurut Depag RI [6] yaitu:

1. Ikut merasakan

Kemampuan dalam hal untuk mengetahui perasaan yang dialami oleh orang lain, sehingga dengan ini ia akan merasakan sebuah emosi yang dapat mengidentifikasi 
perasaan yang dialami oleh orang lain. Ikut merasakan adalah seorang pendidik dapat merasakan apa yang dirasakan oleh muridnya.

Contoh ikut merasakan adalah pendidik ikut merasa senang apabila seorang muridnya mendapat prestasi yang baik.

2. Dibangun atas kesadaran sendiri

Artinya semakin kita memahami emosi diri sendiri maka akan semakin terampil kita merasakan perasaan orang lain. Kesadaran sendiri adalah apabila sesorang melakukan suatu tindakan tidak didasar atas paksaan dari orang lain.

Contoh kesadaran sendiri adalah pendidik memberikan bantuan kepada muridnya tanpa ada paksaan dari pihak lain.

3. Peka terhadap bahasa isyarat

Seseorang harus mempunyai kepekaan akan bahasa isyarat dari orang lain, hal ini dikarenakan seseorang lebih sering mengungkapkan permasalahan yang dihadapinya mengunakan bahasa isyarat. Sehingga dengan ini seseorang harus mampu memahami apa yang dialami oleh orang lain yang bisa terungkap dari bahasa nonverbal sepertihalnya bahasa tubuh, gerak-gerik, ekspresi wajah dan lain sebagainya.

Peka terhadap bahasa isyarat dapat berupa seorang pendidik mengetahui jika seorang murid yang tidak mengerti dalam belajar dengan ekpresi wajah murid tersebut.

4. Mengambil peran

Perasaan empati akan membentuk sebuah tindakan yang lebih konkret. Apabila seseorang menyadari apa yang dirasakannya setiap saat, maka perasaan emaprti tersebut akan muncul dengan sendirinya tanpa adanya rangsangan dari manapun.

Mengambil peran dapat merupa tindakan yang dilakukan seseorang. Mengambil peran dapat berupa seorang pendidik harus mampu menjadi orang tua dalam belajar untuk muridnya karena orang tua harus bisa memberikan ilmu yang baik bagi anak-anaknya.

Jadi dapat disimpulkan bahwa perhatian dan empati adalah sikap yang ditunjukkan kepada seseorang yang dapat memerikan pengaruh kepada orang yang diberilkan pehatian dan empati begitu juga dalam belajar sikap perhatian dan empati yang yan diberikan pendidik dapa memberikan pengaruh besar terhadap sikap murid dalan belajar. Sejalan dengan penjelasan, hasil temuan penelitian mengenai gambaran kepedulian pendidik dilihat dari dari perhatian dan empati pendidik terhadap murid di TPQ Nurul Yaqin Jrg. Kp.Tujuh Nag.Tj,.Betung Kec. Rao Selatan Kab. Pasaman sudah dikategorikan cukup tinggi.

\section{SIMPULAN DAN SARAN}

Berdasarkan hasil penelitian dan pembahasan tentang kepedulian pendidik di TPQ Nurul Yaqin Jrg. Kp. Tujuh Nag.Tj. Betung Kec. Rao Selatan Kab. Pasaman kesimpulannya ialah: 1) Gambaran kepedulian pendidik dilihat dari pemahaman pendidik terhadap murid di TPQ Nurul Yaqin sudah dikatakan cukup tinggi, dibuktikan dengan banyaknya murid/responden memberikan pernyataan sangat setuju (SS) yang cukup banyak dan pendidik dapat memberikan pelajaran sesuai dengan keadaan murid tersebut; 2) Gambaran kepedulian pendidik dilihat dari kesadara pendidi terhadap murid di TPQ Nurul Yaqin cukup tinggi, dibuktikan dengan sikap kesadaran pendidik dalam 
membatu kesulitan murid dalam belajar tanpa ada paksaan, dan juga dibuktikan dengan persentase pernyataan sangat setuju (SS) yang cukup tinggi; dan 3) Gambaran kepedulian pendidik dilihat dari perhatian dan empati pendidik terhadap murid di TPQ Nurul Yaqin sudah dikatan cukup tinggi, hal itu dibuktikan dengan tingginya persentase pernyataan sangat setuju (SS) yang tinggi.

Sehubungan dengan kesimpulan yang telah dikemukakan sebelumnya, maka penulis menyarankan: 1) Kepada pendidik agar tetap meningkatkan pemahaman, kesadaran, perhatian dan empati dalam proses belajar agar hasil belajar yang diperoleh semakin baik pula dan juga bisa menjadi pendidik yang menyenangkan bagi setiap murid; dan 2) Kepada peneliti selanjutnya dapat menjadi pedoman untuk meneliti tentang kepedulian pendidik lainnya.

\section{UCAPAN TERIMA KASIH (Opsional)}

Terimakasih saya ucapkan kepada TPQ Nurul Yaqin yang telah mengizinkan saya untuk melaksanakan penelitian dalam rangka menyelesaikan tugas akhir yaitu skripsi, dan juga tidak lupa saya ucapkan terimakasih kepada keluarga dan teman-teman yang telah membantu dalam penelitian ini.

\section{REFERENSI}

[1]. Agus, A. R. (2013). Psikologi Sosial: Integrasi Pengetahuan Wahyu dan Pengetahuan Empirik. Jakarta: rajawali pers.

[2]. Aini, W. (2006). Bahan Ajar Konsep Pendidikan Luar Sekolah. Padang: PLS FIP UNP.

[3]. Chaplin. (2001). Kamus Lengkap Psikologi: Alih Bahasa Kartono. Jakarta: Raja Grafindo Persada.

[4]. Latipun. (2006). Psikologi Konseling. Malang: UMM Press.

[5]. Muhrima A. Kau. (2010). Empati dan Perilaku Prososial Pada Anak. Jurnal Inovasi, 7(3), 1-5. Retrieved from http://ejurnal.ung.ac.id/index.php/JIN/article/download/771/714

[6]. Saam, Z. (2013). Psikologi Konseling. Jakarta: Rajawali Pers.

[7]. Slameto. (2010). Belajar dan Faktor-Faktor yang Mempengaruhinya. Jakarta: Rineka Cipta.

[8]. Undang-undang No. 20 tahun 2003 Tentang Sistem Pendidikan Nasional. (2003). Jakarta: Departemen Pendidikan Nasional.

[9]. Wardani, A. S. (2008). Studi tentang Kesadaran Pekerja terhadap Pelaporan Kecelakaan Kerja di PR Astra Nissan Diesel Indonesia Periode Juni-Juli Tahun 2008. Universitas Indonesia.

[10]. Yusuf, A. M. (2016). Metode Penelitian Kuantitatif, Kualitatif \& Penelitian Gabungan. Jakarta: Prenadamedia. 